\title{
Comparison of Physical-mechanical and Mould-proof Properties of Furfurylated and DMDHEU-modified Wood
}

\author{
Wanju Li, ${ }^{\mathrm{a}, \mathrm{b}}, *$ Lifang Chen, ${ }^{\mathrm{a}, \mathrm{b}}$ and Xingwei $\mathrm{Li}^{\mathrm{a}}{ }^{\mathrm{a} b}$
}

In this study, 1,3-dimethylol-4,5-dihydroxyethyleneurea (DMDHEU) and furfuryl alcohol (FA) modification catalyzed by acrylic acid were comparatively studied. The effects on physical-mechanical properties and durability against mould of Masson pine and Camphor pine wood were investigated, including weight gain rate (WPG), moisture uptake, equilibrium moisture content (EMC), anti-swelling efficiency (ASE), parallel-to-grain compressive strength (CS), modulus of rupture (MOR), and mould resistance. The wood samples modified with DMDHEU closely retained their original color and texture, whereas the color of furfurylated wood became dark brown and the texture became clearer. The WPG of DMDHEU-treated wood ranged from $17.9 \%$ to $29.3 \%$, which was lower than that of furfurylated wood that ranged from $36.7 \%$ to $39.3 \%$. The equilibrium moisture content of DMDHEU-modified wood was slightly higher than the untreated wood, while furfurylation decreased the EMC of wood by approximately $50 \%$ compared with the untreated wood. The dimensional stability, parallel-to-grain compressive strength, and mildew resistance of Masson pine and Camphor pine improved after both modifications noticeably. It was concluded that acrylic acid can be utilized as a catalyst to perform wood furfurylation and DMDHEU modification.

Keywords: Wood; DMDHEU; Furfurylation; Acrylic acid; Mould-proof properties

Contact information: a: Department of Wood Protection, Guangdong Academy of Forestry, Guangzhou 510520, P. R. China; $b$ : Guangdong Provincial Key Laboratory of Silviculture, Protection and Utilization, Guangdong Academy of Forestry, Guangzhou, 510520, P. R. China;

* Corresponding author: liwanju2011@126.com

\section{INTRODUCTION}

Chemical modification has been recognized as an efficient strategy for dimensional stabilization of wood and protecting it from environmental damage (Xie et al. 2013). Wood chemical modification involves techniques where chemical and/or physical methods are applied to permanently alter the properties of wood cell walls through cell wall bulking, hydroxyl group deactivation, and/or filling the lumens with the chemicals to provide persistent protection to in-service wood (Hill 2006). The chemicals must have a small molecular size to penetrate wood micropores and be cured in wood cells (Klüppel and Mai 2013). Chemical modifications to wood, including heat-treatment, acetylation, modification with formaldehyde-based and N-methylol resins, and furfurylation, have been studied; some have been successfully applied in industrial production in recent decades (Xie et al. 2013). N-methylol compounds, such as 1,3-dimethylol-4,5-dihydroxyethyleneurea (DMDHEU), are widely used in the textile industry as finishing agents, and have successfully been used as wood modifying agents (Krause et al. 2003; Gérardin 2016; Emmerich et al. 2019; Kurt and Tomak 2019). Furfuryl alcohol is a low-molecular organic chemical with a strong polarity derived from corn cobs or sugar cane. It can be used to

Li et al. (2019). "Furfurylated \& DMDHEU-mod. wood," BioResources 14(4), 9628-9644. 9628 
improve several wood properties, including dimensional stability, hardness, modulus of rupture (MOR), modulus of elasticity (MOE), resistance to decay, and insect attacks (Epmeier et al. 2004; Lande et al. 2004; Hadi et al. 2005; Esteves et al. 2011; Li et al. 2015). Both DMDHEU and furfurylation are generally completed using acid-based catalysts and high-temperature treatment (Wewerka 1968; Barr and Wallon 1971; Krause et al. 2003; Xie et al. 2008).

Although an industrial process for wood furfurylation and modification based on DMDHEU has been developed and patented, investigations continue to be conducted on the use of furfuryl alcohol and DMDHEU for wood modification. Catalysts play a key role in the wood modification process. They should give the modifier formulation a long pot life, as well as ensure rapid polymerization when heated. Furthermore, the catalyst should have a small molecular weight, as well as similar affinity for wood substances and modifiers, as this ensures deep penetration into the wood cell wall without separation from the modifier. Both $\mathrm{AlCl}_{3} \cdot 6 \mathrm{H}_{2} \mathrm{O}$ and tartaric acid were used for DMDHEU-modified Southern pine (Nicholas and Williams 1987). However, the catalyst led to the development of cracks in treated wood samples due to uneven distribution of DMDHEU, which resulted in the reduction of MOR. After that, magnesium chloride $\left(\mathrm{MgCl}_{2}\right)$, zinc nitrate $\left(\mathrm{Zn}\left(\mathrm{NO}_{3}\right)_{2}\right)$, magnesium nitrate $\left(\mathrm{Mg}\left(\mathrm{NO}_{3}\right)_{2}\right)$, and citric acid were used as catalysts to attempt to accelerate the cross-linking reaction of DMDHEU (Petrič et al. 2007; Xie et al. 2008; Yuan et al. 2013). Magnesium chloride $\left(\mathrm{MgCl}_{2}\right)$ has been found to be the most suitable catalyst for wood DMDHEU modification. However, some degree of strength loss of the treated wood is induced during the modification (Xie et al. 2007; Dieste et al. 2008; Emmerich et al. 2019). Similarly, the catalyst selection process for furfurylation of wood has gone through a long process. Zinc chloride was the initial catalyst used for wood furfurylation (Goldstein and Dreher 1960). However, zinc chloride easily separates from FA during penetration, with devastating effects on cellulose degradation and the long-term strength properties of treated wood (Anaya 1987). Schneider (1995) and Westin (1995) simultaneously developed alternative efficient catalysts using cyclic carboxylic for furfurylation of wood, citric acid, and maleic anhydride, which are the most studied catalysts in wood furfurylation (Lande et al. 2004, 2008; Venas and Rinnan 2008; Thygesen et al. 2010; Pfriem et al. 2012). Additionally, Baysal et al. (2004) reported that borates could be used as catalyst to perform furfurylation to improve the dimensional stabilization of wood. The authors have proposed a composite acidic catalyst for wood furfurylation in a previous study, which produced furfurylated wood with excellent mechanical and durable properties comparable to the widely used maleic anhydride, with less required FA and a lower cost (Li et al. 2015). Recently, Sejati et al. (2017) studied furfurylation of beech wood using five different catalysts; in addition to citric acid and maleic anhydride, maleic acid, itaconic acid, and tartaric acid were also studied. They indicated that tartaric acid can be considered as a new promising catalyst to perform wood furfurylation.

Both Masson pine (Pinus massoniana Lamb.) and Camphor pine (Pinus sylvestris var. mongolica Litv.) are the main tree species that need to be treated with preservatives before use in southern China. The aim of the study is to evaluate the feasibility of acrylic acid as a catalyst to perform wood furfurylation and DMDHEU modification of Masson pine and Camphor pine wood. Weight gain rate (WPG), moisture uptake, equilibrium moisture content (EMC), anti-swelling efficiency (ASE), parallel-to-grain compressive strength (CS), MOR, and mould resistance were selected as characterization parameters.

Li et al. (2019). "Furfurylated \& DMDHEU-mod. wood," BioResources 14(4), 9628-9644. 9629 
Furthermore, scanning electron microscopy (SEM) was used to investigate the effect of different modification on the wood's microstructure.

\section{EXPERIMENTAL}

\section{Materials}

Sapwood specimens of Masson pine (Pinus massoniana Lamb.) and Camphor pine (Pinus sylvestris var. mongolica Litv.) were bought from vendors in Guangdong Province of China. Wood samples were cut from sawn lumber with a thickness of $4 \mathrm{~cm}$. They were dried at $103{ }^{\circ} \mathrm{C}$ until oven-dry state was achieved, weighed, then conditioned in $23{ }^{\circ} \mathrm{C}$ and $65 \%$ relative humidity for at least 30 days before the treatment. Wood samples were prepared according to GB/T 1928 (2009) (Table 1).

Table 1. Information of Wood Samples

\begin{tabular}{|c|c|c|}
\hline Parameter & Sample Size $(\mathrm{T} \times \mathrm{R} \times \mathrm{L})$ & Number of Samples / Groups \\
\cline { 1 - 3 } WPG & $20 \mathrm{~mm} \times 20 \mathrm{~mm} \times 20 \mathrm{~mm}$ & 10 \\
\cline { 1 - 3 } ASE & $20 \mathrm{~mm} \times 20 \mathrm{~mm} \times 30 \mathrm{~mm}$ & 10 \\
\cline { 1 - 3 } EMC & $10 \mathrm{~mm} \times 10 \mathrm{~mm} \times 160 \mathrm{~mm}$ & 10 \\
\cline { 1 - 3 } CS & $20 \mathrm{~mm} \times 5 \mathrm{~mm} \times 50 \mathrm{~mm}$ & 24 \\
\hline Mor & &
\end{tabular}

\section{Methods}

Solution preparation

Furfuryl alcohol (light yellow liquid, $\geq 98 \%$ purity) and DMDHEU were bought from Hongshuolin Company (Guangzhou, China). Buffering agents were purchased from Sinopharm Chemical Reagent Co., Ltd. (Shanghai, China). Other chemicals that were used were of analytical grade, and all solutions were prepared with deionized water. The modification solution was prepared at room temperature, containing weight percentages of $50 \%$ DMDHEU (50 to 55\% solid content) or FA and 5\% acrylic acid as the catalyst. Water, buffering agents, catalyst, and DMDHEU or FA were added in that order.

\section{Impregnation and polymerization}

The samples and solutions were placed in a plastic box, and an iron gauze was used to press down the samples to prevent them from floating on the surface of the solution. The plastic box was placed in a tank and pressure treatment was applied. This process consisted of treatment in a vacuum for $15 \mathrm{~min}$ followed by $1.5 \mathrm{MPa}$ of pressure for $30 \mathrm{~min}$, then immersion in a modification solution for $16 \mathrm{~h}$ at normal pressure. The impregnated wood specimens were then wrapped in aluminum foil to avoid evaporation of the solution during the curing stage. The samples were cured at $95^{\circ} \mathrm{C}$ for $3 \mathrm{~h}$. After polymerization, the treated samples were further dried at $105^{\circ} \mathrm{C}$ until an oven-dried state was achieved.

\section{Physical and mechanical properties testing}

The physical and mechanical properties of all the samples were tested according to Chinese National Standards GB/T 1931 (2009) and GB/T 1934.2 (2009). 
The WPG of modified wood was calculated using Eq. 1, which represents the weight changes caused by the modification,

$$
\text { WPG }(\%)=\frac{M_{1}-M_{0}}{M_{0}} \times 100
$$

where $M_{1}$ and $M_{0}$ are the oven-dry mass (g) of wood before and after modification, respectively.

To determine the wettability of treated and untreated wood, the treated and untreated wood blocks were weighed and soaked with deionized water in a glass container. They were then collected and weighed after 1, 5, 10, 15, 20, and $30 \mathrm{~d}$. The water uptake (WU) was calculated according to Eq. 2,

$$
\mathrm{WU}(\%)=\frac{M_{\mathrm{wet}}-M_{\mathrm{dry}}}{M_{\mathrm{dry}}} \times 100
$$

where $M_{\text {wet }}$ and $M_{\text {dry }}$ are the weight (g) of wood after absorption of water and the ovendried weight ( $\mathrm{g}$ ) of the wood samples, respectively.

The dimensional stability of wood was characterized by ASE. The dimensional stability of the dry and wet treated wood was measured. The tangential, radial, and longitudinal sizes were recorded. The ASE was calculated according to Eqs. 3 and 4,

$$
\begin{aligned}
& \alpha(\%)=\frac{V_{\text {wet }}-V_{\text {dry }}}{V_{\text {dry }}} \times 100 \\
& \operatorname{ASE}(\%)=\frac{\alpha_{0}-\alpha_{1}}{\alpha_{0}} \times 100
\end{aligned}
$$

where $V_{\text {wet }}$ and $V_{\text {dry }}$ are the size $(\mathrm{mm})$ of the modified wood samples in wet and dry states, respectively, and $\alpha_{0}$ and $\alpha_{1}$ represent the coefficient of wet expansion of the untreated and modified wood samples, respectively.

The MOR and MOE of wood were tested according to the Chinese national standard GB/T 1936.1 (2009). The previously conditioned $10 \mathrm{~mm} \times 160 \mathrm{~mm} \times 10 \mathrm{~mm}(\mathrm{~T}$ $\times \mathrm{L} \times \mathrm{R}$ ) wood samples were tested in a three-point bending model using a universal mechanical testing machine (AGS-X plus-50 kN; Shimadzu, Tokyo, Japan). The machine was operated with a span of $120 \mathrm{~mm}$ and a displacement-controlled testing speed of 2 $\mathrm{mm} / \mathrm{min}$. The MOR and MOE were determined with Eqs. 5 and 6, respectively,

$$
\begin{aligned}
& \mathrm{MOR}=\frac{3 P_{\max } L}{2 \mathrm{~b} h^{2}} \\
& \mathrm{MOE}=\frac{P_{p} L^{3}}{4 \delta b h^{3}}
\end{aligned}
$$

where $P_{\max }$ is the maximum load $(\mathrm{N}), L$ is the testing span of the samples $(\mathrm{mm}), b$ is the width of the samples $(\mathrm{mm}), h$ is the thickness of the samples $(\mathrm{mm}), P_{\mathrm{p}}$ is the load difference $(\mathrm{N})$ between the upper and lower boundary loads within the proportional limit, and $o$ is the mid-span deflection $(\mathrm{mm})$ of the sample under $P_{\mathrm{p}}$.

The parallel-to-grain compressive strength of wood was tested according to the Chinese national standard GB/T 1935 (2009). Samples with sizes of $20 \mathrm{~mm} \times 30 \mathrm{~mm} \times 20$ $\mathrm{mm}(\mathrm{T} \times \mathrm{L} \times \mathrm{R})$ were loaded with a constant loading rate, and the maximum compressive load that the sample could withstand for more than $90 \mathrm{~s}$ without collapse was recorded. 


\section{Simple mould tests}

Simple mould tests were performed in a climate chamber with controlled relative humidity (RH) and temperature, with a similar method used by Ahmed et al. (2013). Glass tubes were attached to the top of the chamber (Fig. 1). Each sample was hung from the supporting glass tubes. A 10-mm minimum gap was maintained between the two samples. Aspergillus niger V. Tiegh, Penicillium citrinum Thom, Trichoderma viride Pers. ex Fr., and Botryodiplodia theobromae Pat. were applied to infect the samples. The petri dish covered with molds was placed in the lower part of the climate chamber to infest the chamber with spores. The infected samples were kept for one month in the climate chamber. Mold growth on each sample was visually rated according to the criteria described in the Chinese National Standard GB/T 18261 (2013).

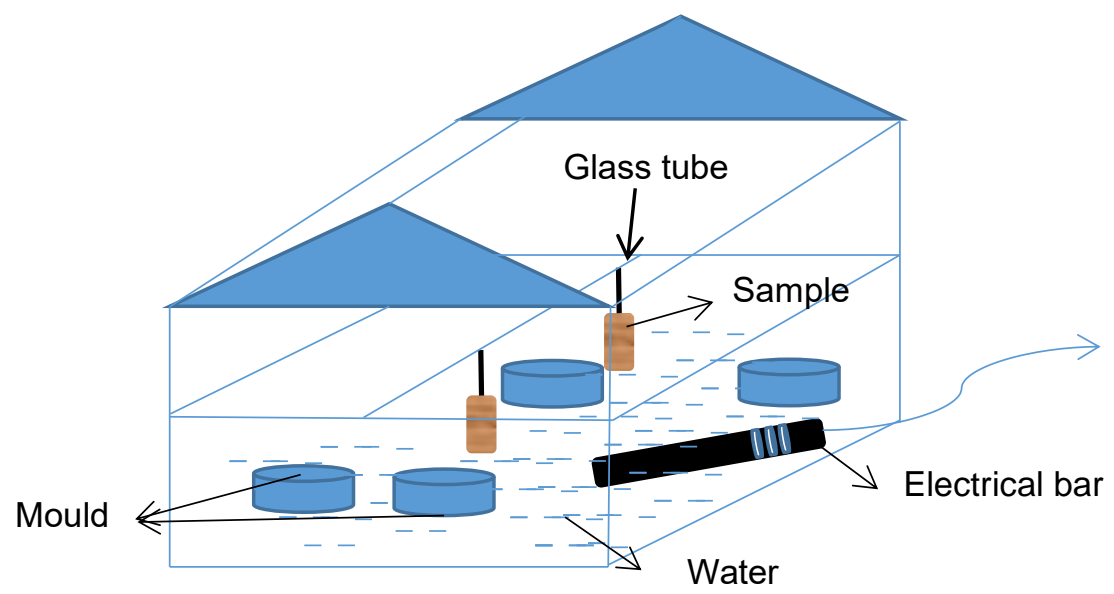

Fig. 1. Schematic of the climate chamber. An electrical bar was used to heat the water to maintain the temperature and humidity in the climate chamber

Scanning electron microscope (SEM) analysis of wood

Prior to SEM analysis, the specimens were coated in gold (Electron Microscopy China, Beijing, China). The cross and longitudinal sections of wood samples were scanned for macroscopic inspection. The samples were then examined using a scanning electron microscope (ZEISS SUPRA 40; Carl Zeiss, Jena, Germany) operating at an accelerating voltage of $30 \mathrm{kV}$.

\section{RESULTS AND DISCUSSION}

\section{Physical Properties}

The DMDHEU can form an interaction between hydroxyl groups and cross-link the wood cell wall (Gérardin 2016). Furfurylation of wood is based on in situ polymerization of furfuryl alcohol, which produces a branched polymer via connection of methylene groups and/or dimethylene ether groups (Barsberg and Thygesen 2009). No matter how different the modification mechanism, the penetration of modifiers in the cell wall is necessary to impart new properties on the treated wood. As shown in Fig. 2, the wood samples modified with DMDHEU almost retained their original color and texture, whereas the color of furfurylated wood became dark brown and the texture became clearer. After DMDHEU modification, $17 \pm 4 \%$ and $29 \pm 3 \%$ WPGs were observed for modified Masson 
pine and Camphor pine wood, respectively. This result suggested that the use of acrylic acid as a catalyst can perform the reaction of DMDHEU in wood, but the amount of catalyst that is used needs to be further optimized. Furthermore, whether there are amounts of monomeric acrylic acid in the treated wood needs to be considered. A previous study suggested that DMDHEU and acrylic acid could be used to synthesize the DMDHEU-AA products for cotton fabrics treatment, and the crosslinking between cellulose and the COOH of the DMDHEU-AA was confirmed (Chen et al. 2001). Therefore, the presence of unreacted monomers probably could be avoided. The WPG was slightly lower than has been previously reported in systems catalyzed by other catalysts. Mamiński et al. (2016) observed $36 \pm 4 \%$ and $22 \pm 6 \%$ WPGs for modified oil palm (Elaeis guineensis Jacq.) waste trunk, with $34 \%$ and $17 \%$ DMDHEU, respectively, containing 5 wt $\%$ ptoluenesulfonic acid (p-TSA) used as the catalyst. Dieste et al. (2008) modified Betula sp. and Fagus sylvatica plywood with $0.8 \mathrm{M}$ to $2.3 \mathrm{M}$ DMDHEU using $4 \%$ magnesium nitrate as the catalyst, gaining the WPG of treated wood was between $6 \%$ and $35 \%$. The material they modified was not solid wood, which is one of the factors to consider. In contrast, higher WPGs appeared in furfurylation of Masson pine and Camphor pine wood, ranging between $20.9 \%$ to $35.9 \%$ and $37.9 \%$ to $44.4 \%$ with averages of $25.2 \%$ and $39.2 \%$, respectively. Esteves et al. (2011) treated Pinus pinaster with a 70\% FA mixture and found an average WPG of 38\%. Sejati et al. (2017) reported that the WPG of European beech (Fagus sylvatia L.) furfurylated with 50\% FA and 5\% tartaric acid catalyst was $40.7 \%$ for larger samples. The result indicated that acrylic acid can also perform the reaction of furfuryl alcohol in wood and obtain comparable results.

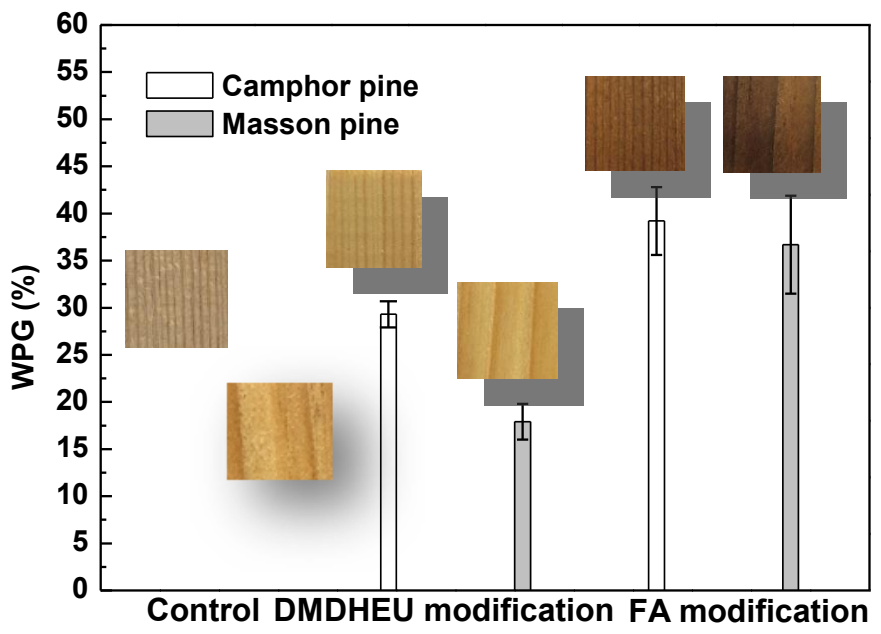

Fig. 2. The WPG of modified Masson pine and Camphor pine wood

The equilibrium moisture content (EMC) of untreated and modified wood is shown in Fig. 3, for which the measurements were done after conditioning in a controlled environment at $20{ }^{\circ} \mathrm{C}$ and $65 \%$ relative humidity for 30 days. The EMC of furfurylated Masson pine and Camphor pine wood decreased $44 \%$ from $8.5 \%$ to $4.8 \%$. These results showed a clear decrease in EMC that was consistent with the results of other researchers (Epmeier et al. 2007; Esteves et al. 2011). In contrast, the EMC of DMDHEU-modified wood did not decrease, but it presented a higher EMC than those of untreated Masson pine 
and Camphor pine wood. This meant DMDHEU-modified wood absorbed more moisture than the control wood. According to most previous studies, DMDHEU modification can also remarkably reduce the EMC of wood. For example, the EMC of Scots pine and European beech wood treated with $30 \%$ DMDHEU (catalyst $\mathrm{MgCl}_{2}$ ) was reduced $3 \%$ to 4\% (Schaffert et al. 2006). This phenomenon can be attributed to the unreasonable amount of catalyst used for DMDHEU modification. The DMDHEU molecule itself is a hygroscopic substance, with a molecular weight composed of up to $39 \%$ of $\mathrm{OH}$ groups. The reactions of DMDHEU monomers, approved for wood, cause cross-linking of the hydroxyl groups of $(-\mathrm{OH})$ of cellulose and hemicellulose through the reactive functional groups, and polymerization (auto-condensation), which produce molecules that consist of $26 \%$ and $24 \% \mathrm{OH}$ groups, respectively (Emmerich et al. 2019).

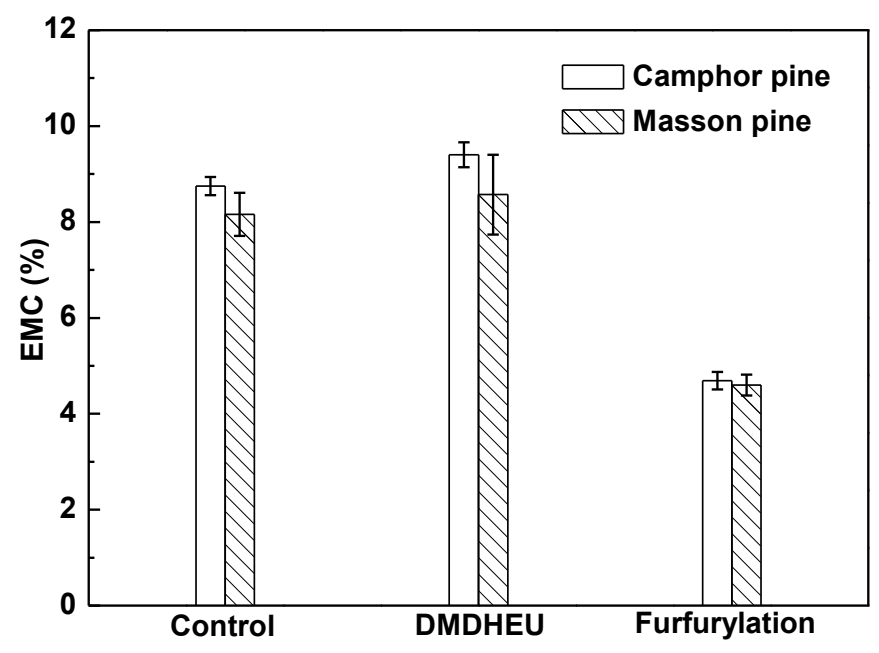

Fig. 3. The EMC of modified Masson pine and Camphor pine wood

Overall, both modifications reduced the rate and amount of water uptake of Masson pine and Camphor pine wood (Fig. 4). A comparative look at the difference in water absorption between Masson pine and Camphor pine wood shows that the former had a lower water uptake than that of the latter after the same soaking time. This difference can be related to structural differences in the different species. Both untreated Masson pine and Camphor pine wood showed a more rapid water uptake than that of modified wood after the same submersion times, except the DMDHEU-modified Camphor pine wood showed quicker water uptake in the first 9 days compared to the untreated wood. Furfurylation caused a greater reduction in water uptake than the DMDHEU modification. The reduction effect of furfurylation was also shown by Treu et al. (2009) and Bastani et al. (2015). Additionally, they found that furfurylated wood with a higher uptake of FA caused a slightly greater reduction in water uptake. The improvement of furfurylated wood hydrophobicity was mainly due to the polymerization of small but polar FA monomers in the wood cell walls. The formed hydrophobic FA resin causes the cell wall to become bulkier and reduces its ability to swell upon water absorption (Dong et al. 2015; Kong et al. 2018). As previously reported, DMDHEU modification also can reduce the water absorption of wood. Coated Scots pine (Pinus silvestris L.) sapwood panels pre-treated with DMDHEU resulted in lower uptake in periodical submersion tests (Xie et al. 2008). Mamiński et al. (2016) reported that $34 \%$ and 17\% DMDHEU-modified palm trunk 
reduced water absorption $48 \%$ and $25 \%$ after 24 h of soaking, respectively. The lower water uptake of the DMDHEU-treated wood is explained by the penetration of DMDHEU into the cell walls and the resulting cell wall bulking, which reduces the number of sites in the cell wall that are available to absorb water molecules (Xie et al. 2008). Furthermore, DMDHEU modification reduces the fibre saturation point by filling micropores that are available for water sorption in the cell walls of untreated wood (Yasuda et al. 1994; Dieste et al. 2008). The DMDHEU fills some of the larger pores, leaving less space for water adsorption; this implies that the control wood absorbs more water than modified wood (Dieste et al. 2009). The phenomena that DMDHEU-modified Camphor pine wood soaked up more water than untreated wood in the first 9 days can be explained by the hygroscopic character of the DMDHEU monomer, which provides additional adsorption sites after modification (Emmerich et al. 2019).

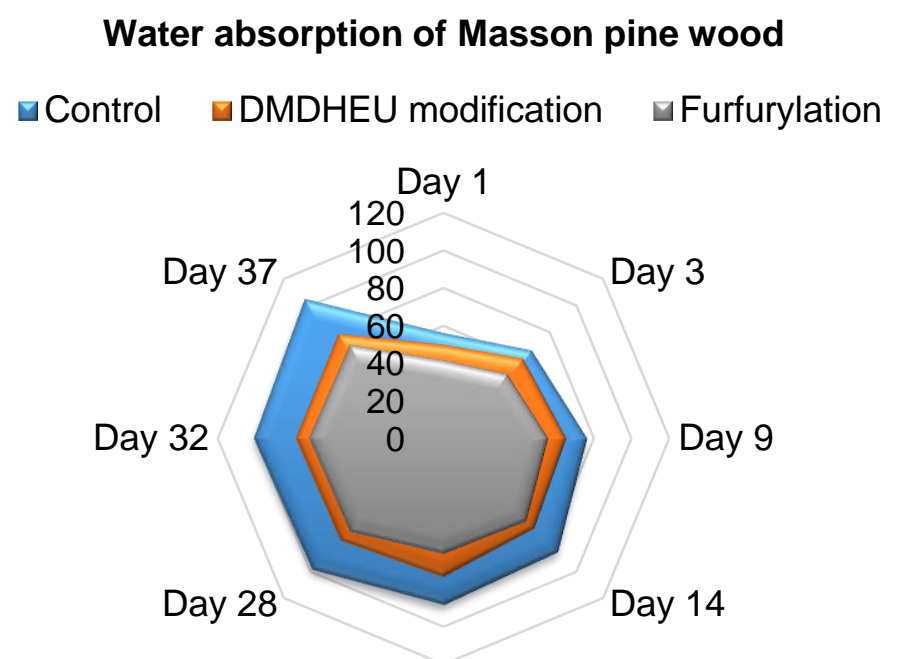

Day 21

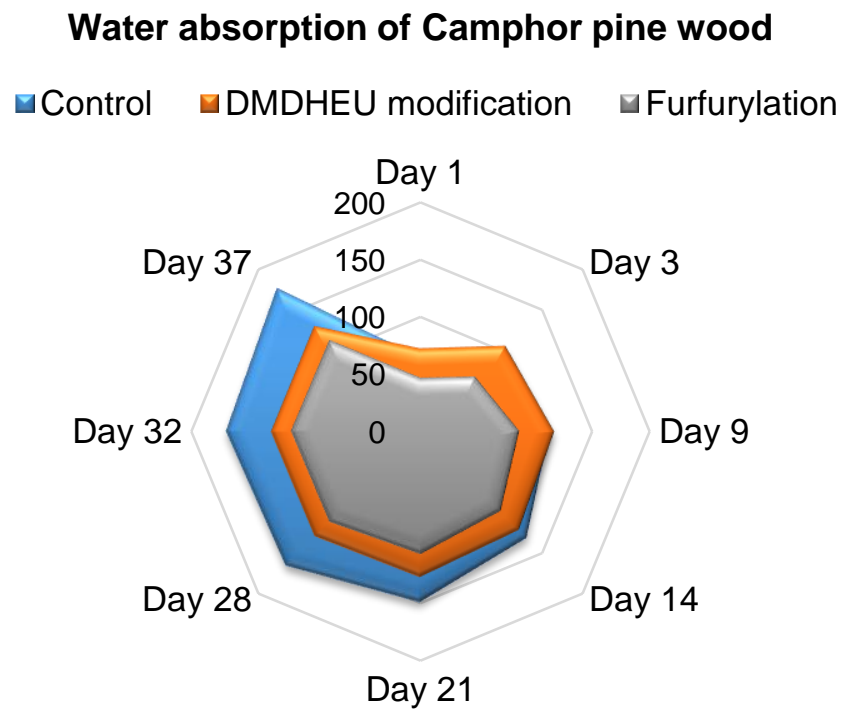

Fig. 4. The water uptake of untreated and modified Masson pine and Camphor pine wood 
Figure 5 summarizes findings that both DMDHEU modification and furfurylation improved the dimensional stability of Masson pine and Camphor pine wood. The ASE in the tangential (T-ASE), radial (R-ASE), and volume (V-ASE) of furfurylated Masson pine on average was $48.2 \%, 40.4 \%$, and $39.3 \%$, respectively, and those of furfurylated Camphor pine on average were $45 \%, 20 \%$, and $26.4 \%$, respectively. Several previous studies have reported that furfurylation can greatly enhance the dimensional stability of wood. Epmeier et al. (2004) and Esteves et al. (2011) reported the ASE of furfurylated Scots pine and Pinus pinaster ranged from $45 \%$ to $50 \%$ when catalyzed by maleic anhydride. In the authors' previous study, the ASE of furfurylated Masson pine wood catalyzed with a composite organic acid catalyst increased on average $47.6 \%, 61.45 \%, 66.41 \%$, and $53.87 \%$ in the tangential, radial, and longitudinal directions, and volumetric, respectively (Li et al. 2015). The average values for the T-ASE, R-ASE, and V-ASE for the Masson pine treated with DMDHEU were 56\%, 29\%, and 47.8\%, respectively, those of DMDHEU-treated Camphor pine were $56.1 \%, 31.6 \%$, and $51.2 \%$, respectively. In contrast, the ASE of DMDHEU-modified wood was higher than that of furfurylated wood. This was explained by the modification mechanism. The dimensional stability increased to a great extent when modification took place in the wood cell walls rather than in cell cavities.

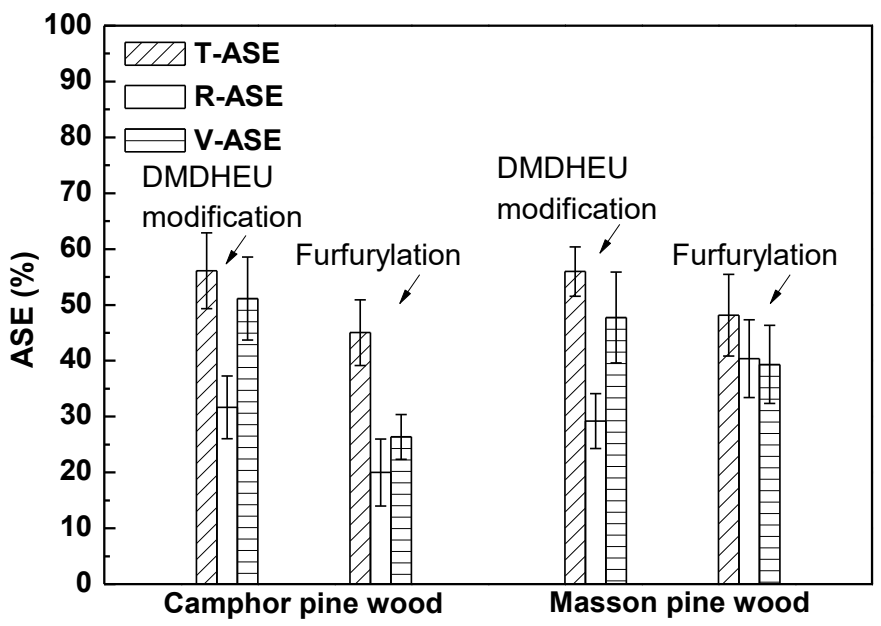

Fig. 5. The ASE of untreated and modified Masson pine and Camphor pine wood

\section{Mechanical Properties}

The compressive tests revealed that the DMDHEU modification and furfurylation had a positive effect on the parallel-to-grain CS, as shown in Fig. 6a. The CS of modified Camphor pine wood increased 50\% relative to the control. For the DMDHEU-modified and furfurylated Masson pine wood, the CS increased $21 \%$ and $51 \%$ relative to the control. Winandy and Rowell (2005) reported that beech wood treated with DMDHEU catalyzed by $\mathrm{MgCl}_{2}$ exhibited an increase in compression strength of up to $65 \%$.

Figure $6 \mathrm{~b}$ shows the effect of modification on the MOR of Masson pine and Camphor pine wood. The MOR of furfurylated Camphor pine and Masson pine wood increased $12.9 \%$ and $25.7 \%$ relative to the untreated wood, respectively. The MOR of DMDHEU-modified Masson pine was only increased 2.8\% relative to the untreated wood, while that of DMDHEU-modified Camphor pine wood decreased $25 \%$ relative to the control. Nicholas and Williams (1987) modified Southern pine with 10\% DMDHEU catalyzed by $0.5 \% \mathrm{AlCl}_{3} \cdot 6 \mathrm{H}_{2} \mathrm{O}$ and $0.5 \%$ tartaric acid and found a reduction of the MOR 
in bending of $37 \%$. Beech wood treated with DMDHEU catalyzed by $\mathrm{MgCl}_{2}$ exhibited only a slight decrease of MOR in bending (Winandy and Rowell 2005). Additionally, Dieste et al. (2008) also reported that the plywood produced with Betula sp. and F. sylvatica and modified with DMDHEU presented no remarkable reduction of bending strength. This can be partly explained by the modified wood's different EMC. Furthermore, acidic modifier solutions will inevitably remove some number of hemicelluloses from wood, which will cause more negative effects on the bending properties. The experimental results showed that the wood samples treated by different modifiers exhibited different failure modes after the bending test. The samples treated by DMDHEU exhibited a regular fractured surface with some fragments and had a certain degree of embrittlement. The failure of the furfurylated wood samples exhibited a similar fracture pattern as that of untreated wood. Xie et al. (2013) found that resin modification can reduce the impact property of wood and increase its brittleness.
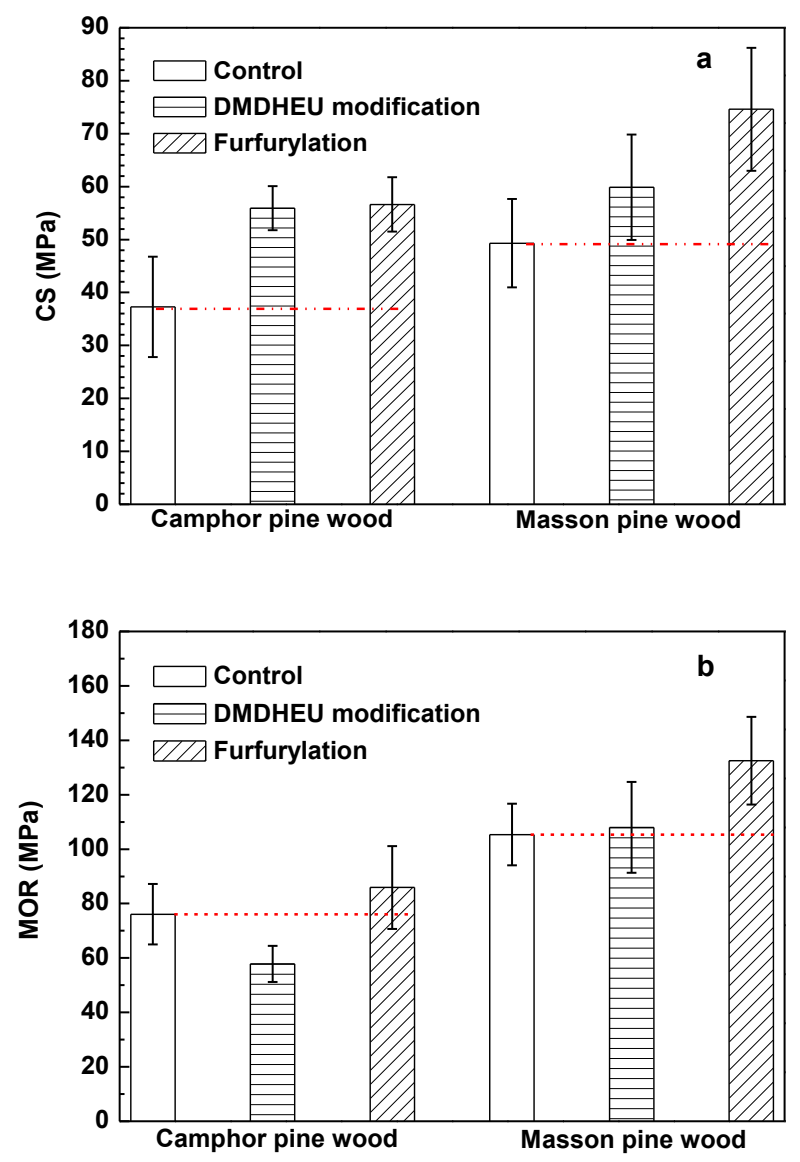

Fig. 6. The effect of modification on the CS and MOR of Masson pine and Camphor pine wood

Figure 7 displays the SEM images of the cross and vertical sections for untreated and modified wood samples. For the cross-section, the natural cellular structure of Masson pine and Camphor pine wood with irregular cell shapes can be observed from the untreated samples. Compared to the untreated wood samples, part of the wood cells with filled lumen and cell walls can be observed from DMDHEU- and furfuryl alcohol-modified wood samples (shown by the arrow in Fig. $7 b_{1} / c_{1} / e_{1} / f_{1}$ ). These results suggested that the wood 
structure could be permanently filled with resins through the chemical reaction. Moreover, the cell inwall of the furfurylated wood samples was smoother and full, which indicated that the furfuryl alcohol modifier penetrated the cell walls more easily. Another important finding was that the cell wall of the DMDHEU-modified wood samples exhibited slight cracks (shown by the arrow in Fig. $7 b_{1}$ and $e_{1}$ ), and many resins were scattered in the lumens. This phenomenon could have been due to the morphology of DMDHEU resins. Compared to the untreated samples, substances were noticeably adhered to the vertical structure of all modified wood samples, which resulted in the smooth lining of the cells and the raised pits' edges. Part of the pits of the modified wood samples were filled with resins. This filling could block the entry of water into the wood, so that the water-induced dimensional change of the wood could be decreased. Furthermore, in DMDHEU-modified wood samples, the intercellular layer exhibited a bulk type with a brittle, ruptured surface (arrow in Fig. $7 b_{2}$ ). This may explain why the MOR of DMDHEU-modified Camphor pine wood decreased.
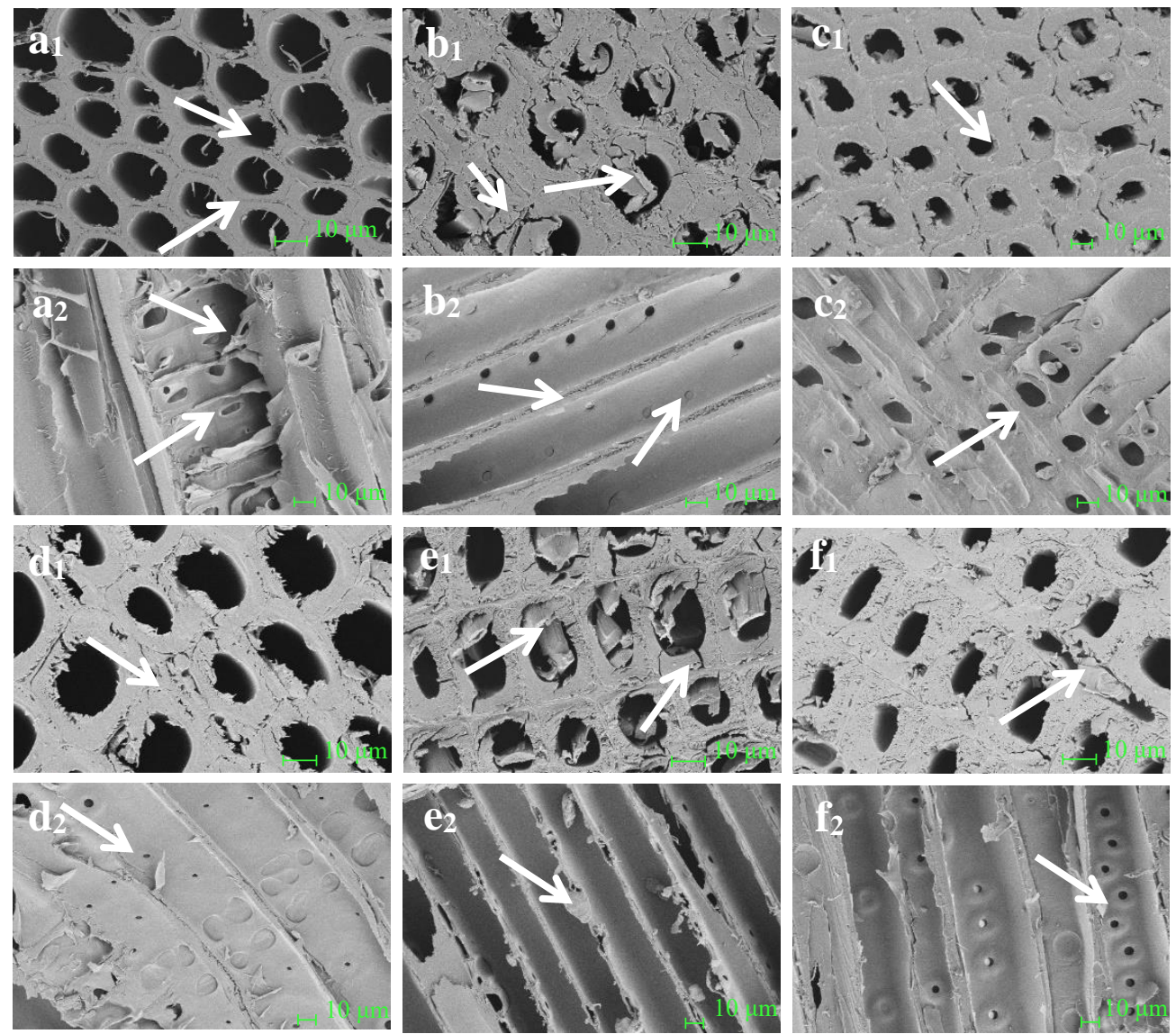

Fig. 7. The SEM morphology of untreated and modified wood samples. Picture $a_{1} a_{2}\left(d_{1} d_{2}\right)$ is from untreated Masson pine and Camphor pine wood; Picture $b_{1} b_{2}\left(e_{1} e_{2}\right)$ is from Masson pine and Camphor pine wood treated by DMDHEU resin; Picture $c_{1} c_{2}\left(f_{1} f_{2}\right)$ is from Masson pine and Camphor pine wood treated by FA resin.

\section{Mould-proof Properties}

Mould tests were performed in a climate chamber with controlled $95 \% \mathrm{RH}$ and a temperature of $25{ }^{\circ} \mathrm{C}$. The results of the mould evaluation of modified Masson pine and 
Camphor pine wood with DMDHEU and furfurylation are summarized in Table 2. The untreated Masson pine and Camphor pine wood showed little resistance to mould exposure and became rapidly covered with mould after one week. After 4 weeks of exposure, the DMDHEU-modified and furfurylated wood showed some excellent resistance to mould growth compared to the untreated samples. After one month of testing, the untreated wood samples were almost covered by Aspergillus niger and Botryodiplodia theobromae. According to the criteria in the Chinese National Standard GB/T 18261 (2013), the mould resistance level reached 4 . In contrast, there was a small amount of hypha infection on the surface of the DMDHEU-modified wood samples and little infection on the surface of the furfurylated wood samples. The mould resistance rating value after four weeks of testing of untreated DMDHEU-modified and furfurylated Masson pine and (Camphor pine wood) was 4 (3.6), $0.96(0.4)$, and 0.05 (0), respectively. The improvement of mold resistance by both modifications can be attributed to multiple factors. First, the entry channel of mold into the wood was blocked (Xie et al. 2008). Second, the reduction in moisture adsorption inhibited fungi growth on the surface of furfurylated wood (Ringman et al. 2014). Furthermore, the introduction of an acidic catalyst during the modification process changed the $\mathrm{pH}$ value of the wood surface and made it unsuitable for mold growth (Wu and Weng 2000).

Table 2. Results of Mould-proof of Untreated and Modified Masson Pine and Camphor Pine Wood

\begin{tabular}{|c|c|c|c|}
\hline \multirow{2}{*}{ Samples } & Treatment & $\begin{array}{c}\text { Average Mildew } \\
\text { Grade }\end{array}$ & $\begin{array}{c}\text { Resistance } \\
\text { Effectiveness (\%) }\end{array}$ \\
\hline \multirow{3}{*}{ Masson Pine } & Control & 4 & 0 \\
\cline { 2 - 4 } & $\begin{array}{c}\text { DMDHEU } \\
\text { modification }\end{array}$ & 0.96 & 76 \\
\cline { 2 - 4 } & Furfurylation & 0.05 & 98 \\
\hline \multirow{3}{*}{ Camphor Pine } & Control & 3.6 & 10 \\
\cline { 2 - 4 } & $\begin{array}{c}\text { DMDHEU } \\
\text { modification }\end{array}$ & 0.4 & 90 \\
\cline { 2 - 4 } & Furfurylation & 0 & 100 \\
\hline
\end{tabular}

In the present study, acrylic acid can be used successfully as a catalyst to perform the reaction of DMDHEU and furfuryl alcohol in wood. However, more measurements and experiments should be conducted to demonstrate that the modification is harmless to human health and environmentally friendly. For example, the formaldehyde emissions should be considered due to DMDHEU monomers are synthesized from urea, glyoxal and formaldehyde (Emmerich et al. 2019). Studies have shown that formaldehyde emissions were affected by curing conditions, reagent concentration and type of reagent (Schaffert et al. 2005; Krause 2006; Bollmus 2011). The relevant investigations are being conducted to optimize catalyst content and curing condition of DMDHEU modification.

\section{CONCLUSIONS}

1. Both DMDHEU modification and furfurylation remarkably improved the physical and mechanical properties and mildew resistance of Masson pine and Camphor pine wood.

Li et al. (2019). "Furfurylated \& DMDHEU-mod. wood," BioResources 14(4), 9628-9644. 9639 
The results showed that acrylic acid can be used successfully as a catalyst to perform the reaction of DMDHEU and furfuryl alcohol in wood.

2. DMDHEU modification almost retained the wood samples' original color and texture, whereas the color of furfurylated wood became dark brown and the texture became clearer. Both modification had a positive effect on the dimensional stability and the parallel-to-grain CS of wood, and the modified wood showed excellent resistance to mould compared to the untreated samples with the more than $76 \%$ resistance effectiveness.

3. There were significant differences in the effects of the two modification methods on EMC and WU of wood. For example, the EMC of furfurylated wood was reduced 50\%, while that of DMDHEU-modified wood was slightly higher than the untreated wood. The results indicated that the use of acrylic acid as a catalyst needs to be further optimized for DMDHEU modification.

\section{ACKNOWLEDGMENTS}

The authors would like to thank the $13^{\text {th }}$ Five-Year National Key Research and Development Program of China (No. 2017YFD0600803) and National Natural Science Foundation of China (No. 31800474) for financial support.

\section{REFERENCES CITED}

Ahmed, S. A., Sehlstedt-Persson, M., and Morén, T. (2013). "Development of a new rapid method for mould testing in a climate chamber: Preliminary tests," European Journal of Wood and Wood Products 71(4), 451-461. DOI: 10.1007/s00107-0130697-0

Anaya, M. (1987). "Impregnation procedure based on furfuryl alcohol monomer into wood and other material," Cuban Patent No. CU21453.

Barr, J. B., and Wallon, S. B. (1971). "The chemistry of furfuryl alcohol resins," Journal of Applied Polymer Science 15(5), 1079-1090. DOI: 10.1002/app.1971.070150504

Barsberg, S., and Thygesen, L. G. (2009). "Poly (furfuryl alcohol) formation in neat furfuryl alcohol and in cymene studied by ATR-IR spectroscopy and density functional theory (B3LYP) prediction of vibrational bands," Vibrational Spectroscopy 49(1), 52-63. DOI: 10.1016/j.vibspec.2008.04.013

Bastani, A., Adamopoulos, S., and Militz, H. (2015). "Water uptake and wetting behaviour of furfurylated, N-methylol melamine modified and heat-treated wood," European Journal of Wood and Wood Products 73(5), 627-634. DOI: 10.1007/s00107-015-0919-8

Baysal, E., Ozaki, S. K., and Yalinkilic, M. K. (2004). "Dimensional stabilization of wood treated with furfuryl alcohol catalysed by borates," Wood Science and Technology 38(6), 405-415. DOI: 10.1007/s00226-004-0248-2

Bollmus, S. (2011). "Biological and technological properties of beech wood after modification with 1.3-dimethylol-4.5-dihydroxyethylurea (DMDHEU)," Dissertation, University of Goettingen, Faculty of Forest Sciences and Forest Ecology, Goettingen.

Li et al. (2019). "Furfurylated \& DMDHEU-mod. wood," BioResources 14(4), 9628-9644. 9640 
Chen, J. C., Yao, W. H., Chen, C. H., and Chen, C. C. (2001). "Degree of crosslinked cotton cellulose with prereacted DMDHEU-AA," Journal of Applied Polymer Science 82(7), 1580-1586. DOI: 10.1002/app.1996

Dieste, A., Krause, A., Bollmus, S., and Militz, H. (2008). "Physical and mechanical properties of plywood produced with 1.3-dimethylol-4.5-dihydroxyethyleneurea (DMDHEU)-modified veneers of Betula sp. and Fagus sylvatica," Holz als Roh-und Werkstoff 66(4), 281-287. DOI: 10.1007/s00107-008-0247-3

Dieste, A., Krause, A., Mai, C., Sèbe, G., Grelier, S., and Militz, H. (2009).

"Modification of Fagus sylvatica L. with 1,3-dimethylol-4,5-dihydroxy ethylene urea (DMDHEU). Part 2: Pore size distribution determined by differential scanning calorimetry," Holzforschung 63(1), 89-93. DOI: 10.1515/HF.2009.023

Dong, Y., Yan, Y., Zhang, S., Li, J., and Wang, J. (2015). "Flammability and physicalmechanical properties assessment of wood treated with furfuryl alcohol and nano$\mathrm{SiO}_{2}$," European Journal of Wood and Wood Products 73(4), 457-464. DOI: 10.1007/s00107-015-0896-y

Emmerich, L., Bollmus, S., and Militz, H. (2019). "Wood modification with DMDHEU (1.3-dimethylol-4.5-dihydroxyethyleneurea)-state of the art, recent research activities and future perspectives," Wood Material Science and Engineering 14(1), 1-16. DOI: 10.1080/17480272.2017.1417907

Epmeier, H., Johansson, M., Kliger, R., and Westin, M. (2007). "Material properties and their interrelation in chemically modified clear wood of Scots pine," Holzforschung 61(1), 34-42. DOI: 10.1515/HF.2007.007

Epmeier, H., Westin, M., and Rapp, A. (2004). "Differently modified wood: Comparison of some selected properties," Scandinavian Journal of Forest Research 19(sup5), 3137. DOI: $10.1080 / 02827580410017825$

Esteves, B., Nunes, L., and Pereira, H. (2011). "Properties of furfurylated wood (Pinus pinaster)," European Journal of Wood and Wood Products 69(4), 521-525. DOI: 10.1007/s00107-010-0480-4

Gérardin, P. (2016). "New alternatives for wood preservation based on thermal and chemical modification of wood-a review," Annals of Forest Science 73(3), 559-570. DOI: $10.1007 / \mathrm{s} 13595-015-0531-4$

Goldstein, I. S., and Dreher, W. A. (1960). "Stable furfuryl alcohol impregnating solutions," Industrial and Engineering Chemistry 52(1), 57-58. DOI: 10.1021/ie50601a039

GB/T 1928 (2009). "General requirements for physical and mechanical tests of wood," Standardization Administration of China, Beijing, China.

GB/T 1931 (2009). "Method for determination of the moisture content of wood," Standardization Administration of China, Beijing, China.

GB/T 1934.2 (2009). "Method for determination of the swelling of wood," Standardization Administration of China, Beijing, China.

GB/T 1935 (2009). "Method of testing in compressive strength parallel to grain of wood," Standardization Administration of China, Beijing, China.

GB/T 1936.1 (2009). "Method of testing in bending strength of wood," Standardization Administration of China, Beijing, China.

GB/T 18261 (2013). "Test method for anti-mildew agents in controlling wood mould and stain fungi," Standardization Administration of China, Beijing, China.

Li et al. (2019). "Furfurylated \& DMDHEU-mod. wood," BioResources 14(4), 9628-9644. 9641 
Hadi, Y. S., Westin, M., and Rasyid, E. (2005). "Resistance of furfurylated wood to termite attack," Forest Products Journal 55(11), 85-88. DOI: 10.1007/s00107-0050048-x

Hill, C. A. S. (2006). Wood Modification: Chemical, Thermal and Other Processes, John Wiley \& Sons, Ltd., Chichester, England.

Klüppel, A., and Mai, C. (2013). "The influence of curing conditions on the chemical distribution in wood modified with thermosetting resins," Wood Science and Technology 47(3), 643-658. DOI: 10.1007/s00226-013-0530-2

Kong, L., Guan, H., and Wang, X. (2018). "In situ polymerization of furfuryl alcohol with ammonium dihydrogen phosphate in poplar wood for improved dimensional stability and flame retardancy," ACS Sustainable Chemistry and Engineering 6(3), 3349-3357. DOI: 10.1021/acssuschemeng.7b03518

Krause, A., Jones, D., Van der Zee, M., and Militz, H. (2003). "Interlace treatmentWood modification with N-methylol compounds," in: Proceedings of the First European Conference on Wood Modification, Ghent, Belgium, pp. 317-327.

Krause, A. (2006). "Wood modification with cross-linking N-methylol compounds". Dissertation, University of Goettingen, Faculty of Forest Sciences and Forest Ecology, Goettingen.

Kurt, R., and Tomak, E. D. (2019). "The effect of DMDHEU modification on physical and biological properties of parallel strand lumbers," Construction and Building Materials 195, 497-504. DOI: 10.1016/j.conbuildmat.2018.11.064

Lande, S., Westin, M., and Schneider, M. (2008). "Development of modified wood products based on furan chemistry," Molecular Crystals and Liquid Crystals 484(1), 367-378.

Lande, S., Westin, M., and Schneider, M. (2004). "Properties of furfurylated wood," Scandinavian Journal of Forest Research 19(5), 22-30. DOI: 10.1080/0282758041001915

Li, W., Wang, H., Ren, D., Yu, Y. S., and Yu, Y. (2015). "Wood modification with furfuryl alcohol catalysed by a new composite acidic catalyst," Wood Science and Technology 49(4), 845-856. DOI: 10.1007/s00226-015-0721-0

Mamiński, M., Kozakiewicz, P., Jaskółowski, W., Chin, K. L., H’ng, P. S., and Toczyłowska-Mamińska, R. (2016). "Enhancement of technical value of oil palm (Elaeis guineensis Jacq.) waste trunk through modification with 1,3-dimethylol-4,5dihydroxyethyleneurea (DMDHEU)," European Journal of Wood and Wood Products 74(6), 837-844. DOI: 10.1007/s00107-016-1086-2

Nicholas, D. D., and Williams, A. D. (1987). "Dimensional stabilization of wood with dimethylol compounds (IRG/WP/ 3412)," in: International Research Group on Wood Protection, Honey Harbor, Ontario, Canada, pp. 1-9.

Petrič, M., Knehtl, B., Krause, A., Militz, H., Pavlič, M., Pétrissans, M., Rapp, A., Tomažiĉ, M., Welzbacher, C., and Gérardin, P. (2007). "Wettability of waterborne coatings on chemically and thermally modified pine wood," Journal of Coatings Technology and Research 4(2), 203-206. DOI: 10.1007/s11998-007-9023-2

Pfriem, A., Dietrich, T., and Buchelt, B. (2012). "Furfuryl alcohol impregnation for improved plasticization and fixation during the densification of wood," Holzforschung 66(2), 215-218. DOI: 10.1515/hf.2011.134 
Ringman, R., Pilgård, A., Brischke, C., and Richter, K. (2014). "Mode of action of brown rot decay resistance in modified wood: A review," Holzforschung 68(2), 239-246. DOI: $10.1515 / \mathrm{hf}-2013-0057$

Schaffert, S., Nunes, L., Krause, A., and Militz, H. (2006). "Resistance of DMDHEUtreated pinewood against termite and fungi attack in field testing according to EN 252. Results after 30 months (IRG/WP/06-40354)," in: 37 $7^{\text {th }}$ Annual Meeting of the International Research Group on Wood Protection, Tromsoe, Norway, pp. 1-10.

Schaffert, S., Krause, A., and Militz, H. (2005). "Upscaling and process development for wood modification with N-methylol compounds using superheated steam," in: The second European Conference on Wood Modification: Wood modification: Processes, Properties and Commercialisation, pp. 161-168.

Schneider, M. H. (1995). "New call wall and cell lumen wood polymer composites," Wood Science and Technology 29(2), 121-127. DOI: 10.1007/BF00229341

Sejati, P. S., Imbert, A., Gérardin-Charbonnier, C., Dumarçay, S., Fredon, E., Masson, E., Nandika, D., Priadi, T., and Gérardin, P. (2017). "Tartaric acid catalyzed furfurylation of beech wood," Wood Science and Technology 51(2), 379-394. DOI: 10.1007/s00226-016-0871-8

Thygesen, L. G., Barsberg, S., and Venas, T. M. (2010). "The fluorescence characteristics of furfurylated wood studied by fluorescence spectroscopy and confocal laser scanning microscopy," Wood Science and Technology 44(1), 51-65. DOI: $10.1007 / \mathrm{s} 00226-009-0255-4$

Treu, A., Pilgard, A., Puttmann, S., Krause, A., and Westin, M. (2009). "Material properties of furfurylated wood for window production," in: $40^{\text {th }}$ Annual Meeting, International Research Group on Wood Protection, Beijing, China, pp. 1-13.

Venas, T. M., and Rinnan, A. (2008). "Determination of weight percent gain in solid wood modified with in situ cured furfuryl alcohol by near-infrared reflectance spectroscopy," Chemometrics and Intelligent Laboratory Systems 92(2), 125-130. DOI: 10.1016/j.chemolab.2008.02.002

Westin, M. (1995). Development and Evaluation of New Alternative Wood Preservation Treatments Mid-term Status Report, Swedish Council for Forestry and Agricultural Research, Stockholm, Sweden.

Wewerka, E. M. (1968). "Investigation of the polymerization of furfuryl alcohol with gel permeation chromatography," Journal of Applied Polymer Science 12(7), 1671-1681. DOI: 10.1002/app.1968.070120716

Winandy, J. E., and Rowell, R. M. (2005). "Chemistry of wood strength," in: Handbook of Wood Chemistry and Wood Composites, R. M. Rowell (ed.), CRC Press, Boca Raton, FL, USA, pp. 303-347.

Wu, K. Y., and Weng, Y. X. (2000). "Bamboo mildew-rotting and its relation with environmental condition," Forest Research 13(1), 63-70.

Xie, Y., Fu, Q., Wang, Q., Xiao, Z., and Militz, H. (2013). "Effects of chemical modification on the mechanical properties of wood," European Journal of Wood and Wood Products 71(4), 401-416. DOI: 10.1007/s00107-013-0693-4

Xie, Y., Krause, A., Militz, H., and Mai, C. (2008). "Weathering of uncoated and coated wood treated with methylated 1,3-dimethylol-4,5-dihydroxyethyleneurea (mDMDHEU)," European Journal of Wood and Wood Products 66(6), 455-464. DOI: $10.1007 / \mathrm{s} 00107-008-0270-4$ 
Xie, Y., Krause, A., Militz, H., Turkulin, H., Richter, K., and Mai, C. (2007). "Effect of treatments with 1,3-dimethylol-4,5-dihydroxyethyleneurea (DMDHEU) on the tensile properties of wood," Holzforschung 61(1), 43-50. DOI: 10.1515/HF.2007.008

Yasuda, R., Minato, K., and Norimoto, M. (1994). "Chemical modification of wood by non-formaldehyde cross-linking reagents," Wood Science and Technology 28(3), 209218. DOI: 10.1007/BF00193329

Yuan, J., Hu, Y. C., Li, L. F., and Cheng, F. C. (2013). "The mechanical strength change of wood modified with DMDHEU," BioResources 8(1), 1076-1088. DOI:

10.15376/biores.8.1.1076-1088

Article submitted: August 13, 2019; Peer review completed: October 2, 2019; Revised version received and accepted: October 16, 2019; Published: October 21, 2019.

DOI: 10.15376/biores.14.4.9628-9644

Li et al. (2019). "Furfurylated \& DMDHEU-mod. wood," BioResources 14(4), 9628-9644. 9644 